\title{
Internal Determinants of Banks' Profitability: A Case Study on Commercial Bank of Ethiopia (CBE)
}

\author{
ZelalemBorena Bono, MSc in Accounting and Finance \\ Lecturer, Accounting and Finance Department, Collage of Business and Economics, WolaitaSodo University, \\ Wolaitasodo, Ethiopia
}

\begin{abstract}
The profitability of banking sector is the most important instrument of financial system for the future of the economy. The objective of this study is to determine by Vector Error correction model (VECM) approach of the bank specific factors that affect the profitability of commercial bank of Ethiopia. The study was conducted to find out the impact internal factors on the profitability of CBE based on Vector Auto Regressive (VAR) model. The study has been conducted on secondary data for a period of thirty six (37) years from 1981-2017. Cointegration and vector error correction model tests are applied to assess the relationship among dependent and independent variables. ROA is used as the performance measure. The internal factors used in this study are Operating Efficiency Ratio, liquidity Risk Ratio, Size of the Bank and asset quality, which are independent variables. A stationary test was carried out using Graphical approach and Augmented Dickey Fuller (ADF) test. Variables have no unit root at first difference at $5 \%$ level of significance. The Johnson co-integration test showed that, there was long run co-integrating relationship between the variables. Based on the result operating efficiency ratio and bank size affects Return on Asset of the Bank significantly and negatively, Loan to Asset Ratio has positively and significantly determined commercial bank of Ethiopia profitability. However Liquidity Ratio Risk has not significant in the long run. The study suggests that focusing and reengineering the banks alongside the key internal drivers could enhance the profitability as well as the performance of the commercial bank Ethiopia (CBE). The regression result of VECM reveals that the one lag value of bank size has positive and significant relationship with ROA. The one lag value and the two lag value of operating efficiency have a positive and significant relationship with real ROA.
\end{abstract}

Keywords: Co-integration, Internal Factors, Return on asset, Unit root, VAR

DOI: $10.7176 / \mathrm{RJFA} / 10-3-08$

\section{Introduction}

\subsection{Background of the study}

The commercial banks are important financial institutions in the financial system and the economy. They accept demand deposits and make loans and provide other services for the public. These banks make a profit by intermediating between depositors (savers) and borrowers (investors). As financial intermediaries, banks play a crucial role in the operation of most economies. Banks require a good management team to enable them to segregate between different level of liquidity, maturity, and risk preferences. As such, the commercial banks must be able to evaluate a borrower's creditworthiness and monitor performance if they are to stay in profit (Ilhomovich, 2009).

The importance of bank profitability can be appraised at the micro and macro levels of the economy. At the micro level, profit is the essential prerequisite of a competitive banking institution and the cheapest source of funds. The basic aim of a bank's management is to achieve a profit, as the essential requirement for conducting any business. At the macro level, a profitable banking sector is better able to withstand negative shocks and contribute to the stability of the financial system. The importance of bank profitability at both the micro and macro levels has made researchers, academics, bank managements and bank regulatory authorities to develop considerable interest on the factors that determine bank profitability (Aburime, 2008).

Commercial banks play a vital role in the economic resource allocation of countries. They channel funds from depositors to investors continuously. They can do so, if they generate necessary income to cover their operational cost they incur in the due course. In other words for sustainable intermediation function, banks need to be profitable. In the last two decades studies have shown that commercial banks in Sub-Saharan Africa (SSA) are more profitable than the rest of the world with an average Return on Assets (ROA) of 2 percent (Flamini et al., 2009). The high profitability in commercial banking business in SSA is the existence of huge gap between the demand for bank service and the supply thereof. That means, in SSA the number of banks are few compared to the demand for the services; as a result there is less competition and banks charge high interest rates. This is especially true in East Africa where the few government owned banks take the lion's share of the market.

The performance of commercial banks can be affected by internal and external factors (Aburime, 2005). These factors can be classified into bank specific (internal) and macroeconomic variables. The internal factors are individual bank characteristics which affect the bank's performance. These factors are basically influenced by the internal decisions of management and board. The external factors are sector wide or country wide factors 
which are beyond the control of the company and affect the profitability of banks. Internal drivers of bank performance or profitability can be defined as factors that are influenced by a bank's management decisions. Such management effects will definitely affect the operating results of banks. Although a quality management leads to a good bank performance, it is difficult, if not impossible to assess management quality directly. In fact, it is implicitly assumed that such a quality will be reflected in the operating performance. As such, it is not uncommon to examine a bank's performance in terms of those financial variables found in financial statements, such as the balance sheet and income statement Krakah and Ameyaw (2010).

In this study, the aim is to extend this particular work and complement previous Commercial Banks of Ethiopia profitability studies by exploring the internal determinants of profitability in Commercial Bank of Ethiopia (CBE). Therefore, the objective of this paper is to identify, analyze and measure the internal determinants of profitability in Commercial Bank of Ethiopia since 1981 to 2017 G.C by using Vector Autoregressive (VAR) model.

\subsection{Background of the organization}

The Commercial Bank of Ethiopia (CBE) is the largest commercial bank in Ethiopia As of June 2015; it had about 303.6 billion Birr in assets and held approximately $67 \%$ of deposits and about $53 \%$ of all bank loans in the country. The bank has around 22,908 employees, who staff its headquarters and its over 1000+ branches positioned in the main cities and regional towns. The latter include 120 branches in the national capital Addis Ababa. CBE's banking network has reached online 783 branches. The bank has reached 1014 branches as of February 12, 2016.

\subsection{Statement of the problem}

Banks play an important role in the economic development of the countries. For instance, they allocate resource and channel funds from savers to investors continuously Okoth et al. 2013). They do so, if they get necessary earnings to cover their operational cost they incur. That is to say, for sustainable intermediation function, banks need to be gainful. Beyond the intermediation function, the financial performance of banks has critical implications for economic growth of countries. Good financial performance rewards the shareholders for their investment. This in turn, gives confidence for additional investment and brings about economic growth. On the other hand, poor bank performance may lead to banking failure and crisis which have negative consequence on the economic growth (Okoth et al. 2013).

Commercial bank of Ethiopia has a critical role to play in financing development of Ethiopia. CBE is needed to provide resources for investment, construction of mega national projects, boost financial market development, finance for import of fertilizers, finance for import of oil and stimulate economic growth. Ethiopia has launched its second Growth and Transformation Plan (GTP-2) which is expected focus on transforming the country to industrialization that in turn demands more financing from commercial banks. Moreover, CBE is the leading bank in financing mega national projects like big hydroelectric dam, sugarcane factories and etc. Planning for further resource and finance requires making commercial banks profitable. So that, having appropriate and up-to date information on the internal determinants of profitability of commercial bank of Ethiopia is more than necessity.

Today it becomes extremely essential for Commercial banks to examine their performance because their survival in the dynamic economic environment will be dependent upon their good performance. So, its wellbeing and successful operation captures the interest of different researchers and other professionals. Thus, a number of studies have examined the determinants of banks' performance in many countries around the world. For instance, Mobeenet at. (2011) for Pakistan banks, Okothet at. (2013) for Kenyan banks. According to different researchers, the banking sector profitability determinants are divided into two main categories, namely the internal determinants and the external determinants. The internal profitability determinants can be accounted and analyzed as bank specific determinants of profitability because they are controllable by the specific bank management.

The profitability of CBE is very important due to the fact that this bank takes more than $60 \%$ market share of banking industry, most outline branches are collects deposit as a result they incur interest expense but not provide loan so that they not earn interest income, most public financing transactions made through this bank, the bank has becoming larger and larger every year, etc. This research tried to assess the internal factors that determine the profitability of CBE. Though a number of studies were conducted in different countries, in Ethiopia context the studies in the area of internal determinants of profitability on individual bank level is scanty. Also few researchers used VAR regression model for analysis. Thus to fill the gap this study tried to answer to the current situation of CBEs performance by using restricted VAR or VECM model of analysis. So that the specific bank level and focus on internal determinants as well as use of VECM makes this thesis work special. 


\subsection{The research Objectives}

The General objective of the study is to determine the internal factors that affect profitability of commercial bank of Ethiopia. The specific objective of the study includes:

* To assess the effect of bank size on the profitability of Commercial bank of Ethiopia(CBE)

* To assess the effect of operating efficiency ratio on the Profitability of Commercial bank of Ethiopia (CBE);

* To assess the effect of liquidity risk ratio on the profitability of Commercial bank of Ethiopia(CBE);

* To assess the effect of loan to Asset ratio on the Profitability of Commercial bank of Ethiopia (CBE);

\subsection{The Research Hypotheses}

Based on the objective, the researcher seeks to test the following 4 alternative hypotheses with respect to the determinants of profitability in Commercial Bank of Ethiopia (CBE):

$\mathrm{H}_{1}$ :Bank size has significant and negative effect on the profitability of $\mathrm{CBE}$,

$\mathrm{H}_{2}$ : Liquidity Risk Ratio has significant and negative effect on the profitability of CBE

$\mathrm{H}_{3}$ :Operational Efficiency has significantly and negatively determine CBE Profitability,

$\mathrm{H}_{4}$ :Loan to Asset Ratio has significantly and positively determine CBE Profitability,

\subsection{Conceptual Framework}

Different empirical evidences suggested that profitability of commercial banks influenced by internal, industrial and macro-economic factors. However this study is concentrated only the internal determinants of profitability or bank specific determinants of profitability in Commercial Bank of Ethiopia (CBE) includes bank size, Liquidity Risk, operating efficiency and loan to asset ratio.

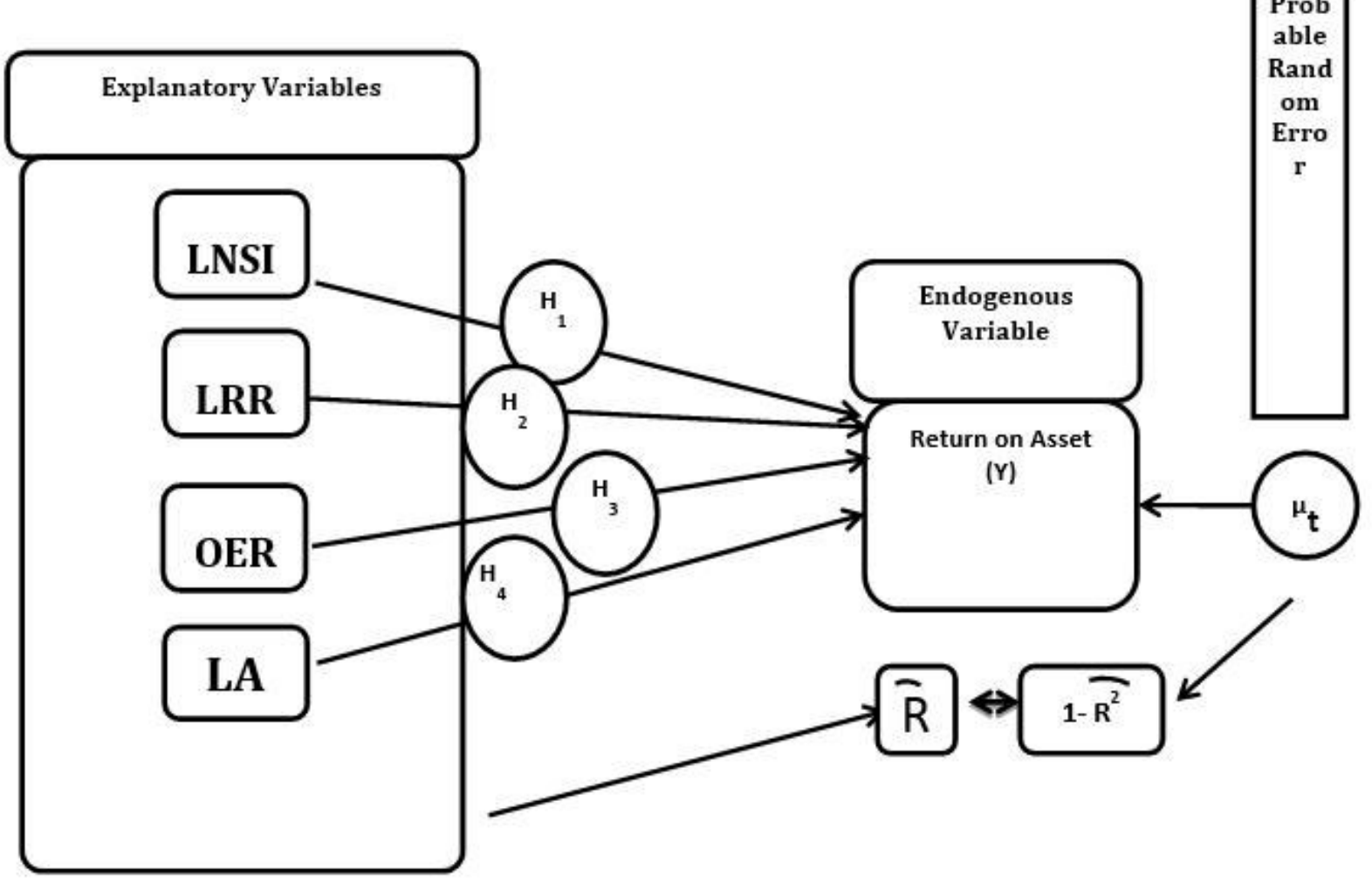

Figure 1 Conceptual frame works of profitability and determinants

Where:

LNSIZE is Natural Logarithms of Bank Size (Asset)

LAR is Loan to Asset Ratio

OER is Operating Efficiency Ratio

LRR is Liquidity Risk Ratio

ROA is Return on Asset

$\mu_{\mathrm{t}}$ is the Error Terms in $\mathrm{t}$ time

$R^{2}$ IsCoefficients of Determination

$\mathrm{H}_{1}, \mathrm{H}_{2} \mathrm{H}_{3}$ and $\mathrm{H}_{4}$ are Research Alternative Hypothesis. 


\section{Literature Review}

\subsection{Definition of Profit and Profitability}

The surplus remaining after total costs are deducted from total revenue and the basis on which tax is computed and dividend is paid. It is the best known measure of success in an enterprise. Profit is reflected in reduction in liabilities, increase in assets, and/or increase in owners' equity. It furnishes resources for investing in future operations, and its absence may result in the extinction of a company. As an indicator of comparative performance, however, it is less valuable than return on asset (ROA) called earnings, (Nugent, 1998).

We know from corporate finance theory that in order for investment in fixed capital to be profitable, the rate of return should at least be equal to the cost of borrowing funds to finance that investment plus a charge for depreciation. In other words, if the initial cost of the investment undertaking is greater than the present value of expected future returns on the investment (i.e. the net present value is negative), then the firm should not proceed with the investment. If the net present value of available investment projects is positive, then in a world without capital rationing, the firm should continue to invest in projects until, at the margin, the firm is indifferent between the investment and the purchase of a government bond. Ultimately, the rate of accumulation of new capital (i.e. the level of net investment) depends on the gap between the rate of return on capital and the cost of capital (Nugent, 1998).

\subsection{Theoretical Framework of Banks Profitability}

There is no general theory of profitability that provides a unifying framework for the study of financial performance determinant of the commercial banking industry. Because of this, this study tries to view some theories which are nearer to the concept of profitability and its determinants.

\subsubsection{Structure-Conduct Performance (SCP)}

The Structure Conduct Performance (SCP) model is one of the earliest frameworks used to examine the factors that determine the profitability of Banks (Grygorenko, 2009). According to Baye (2010), the structure of an industry refers to the factors such as technology, concentration, and market conditions. Conduct refers to how individual firms behave in the market; it involves pricing decisions (such as interest rate, commission and fees), advertising decisions, and decisions to invest in research and development, among other factors. Performance refers to the resulting profits and social welfare that arise in the market. The Structure Conduct Performance (SCP) paradigm views these three aspects of the industry as being integrally related and asserts that the market structure causes firms to behave in a certain way. In turn, this behavior causes resources to be allocated in certain ways leading to either an efficient or inefficient market. This model only fails to recognize that performance can impact on structure and conduct while structure can impact on both performance and conducts.

\subsubsection{Efficiency Hypothesis}

A theoretical attempt to offer an alternative explanation on the market Structure Conduct Performance (SCP) relationship was first made by Demsetz (1973) who also proposed the Efficiency hypothesis. He stated that higher profits of banks are not due to their collusive behaviour but because of high efficiency level, which in turn, leads to larger market shares that banks possess. In other words, profitability of bank is determined not by the market concentration but by bank efficiency (Grygorenko, 2009).

This hypothesis stipulates that a bank which operates more efficiently than its competitors gains higher profits resulting from low operational costs. The same bank holds an important share of the market. Consequently, differences at the level of efficiency create an unequal distribution of positions within the market and an intense concentration (Mensiet al., 2010).

However, Rhoades (1985) doubted the conclusion that the positive relation between market share and profitability was due to efficiency. He stated that this pattern might occur because of product diversification and correspondingly, ability of some banks to set higher prices on their services. According to Grygorenko (2009), further empirical investigations did not bring clarification to the issue as to which of the theories mentioned above is best in explaining bank profitability: Ahmad et al. (1998) and Yu et al., (2005) confirmed StructureConduct-Performance theory, while Mamatzakiset al., (2003) and Naceur (2003) found evidence for EfficientStructure hypothesis.

\subsubsection{Capital Asset Pricing Model}

The Capital Asset pricing Model (CAPM) describes the relationship between risk and expected (required) return. In this model, the expected return on a firm's stock is defined as a function of risk-free rate and a premium based on the systematic risk. The greater the systematic risk, the greater the return the investors will expect from the security. The underlying logic behind this model and its relevance in this study is based on the fact CAPM views the total portfolio risk as a function of systematic risk and unsystematic risk. The systematic risk is attributable to factors that affect the market as a whole such as government policies, changes in the economy and the political climate. The unsystematic risk is specific to a particular company such as industrial relations, quality of firm's management or a new competitor in the industry. Systematic risks cannot be avoided through diversification.

The Asset Pricing Theory (APT) extends the idea of the Capital Asset Pricing Model. This theory asserts 
that in a competitive market arbitrage will assure equilibrium pricing according to risk and return. The security expected return is the risk-free rate plus risk premiums for risk factors which are uncertain (Horne, 2008). The notion is the same as that of the Capital Asset Pricing Model with the exception that we now have multiple risk factors.

\subsubsection{Expense-Preference Behavior}

It is worth noting that profitability or bank returns is not the only measure of performance as used in the theories discussed so far. There are however other theories such as the Expense-Preference Behaviour hypothesis which uses utility instead of profits as a measure of performance. In this theory it is proposed that the main goal which managers pursue is to maximize not profit but own utility or utility of the firm, which is usually achieved via increasing salaries or other staff expenses (Williamson, 1963). We shall go no further on the Expense-Preference Behaviour - as this study is on profitability as a measure of performance.

\subsection{Profitability Measures: Dependent Variables}

The Return on Asset (ROA) and the Return on Equity (ROE) have been used extensively as measures of profitability. ROA indicates how effectively a bank is managing it assets to generate income. ROA is the income earned on each unit of asset usually expressed as percentage. The problem with ROA is that it excludes from the total assets off-balance sheet items (for instance, assets acquired through a lease) thereby understating the value of assets. This can eventually create a positive bias where ROA is overstated in the evaluation of bank performance. Nevertheless, Golin (2001), and Rose et al., (2005) have argued that ROA is one of the most important measures of profitability in recent banking literature. The studies of Haron (2004), Hasanet al., (2003), Bashir (2001), Demirguc-Kuntet al., (1998), Naceur (2003), Alkassim (2005), and Alrashdan (2002) have all adopted ROA as a measure of profitability.

As an alternative measure of profitability the Return on Equity (ROE) is computed by dividing net income by equity. It measures the income earned on each unit of shareholders capital. The shortfall of this measure is that banks with high financial leverage tend to generate a higher ratio. Banks with high financial leverage may be associated with a higher degree of risk although these banks may register high ROE. Thus ROE may sometimes fall short in exposing the true financial health of banks. Another challenge with using ROE is that it is affected by regulation. However, ROE is commonly used in conjunction with ROA.

To evaluate the profitability of banks in this study, the Return on Average Assets (ROAA) and Return on Average Equity (ROAE) is used as measures of profitability. The ROAA and ROAE are slight variations of ROA and ROE respectively in that, instead of using the total assets at the end of the financial period in the denominators of the ratio, the average of the beginning balance and closing balance is rather utilised in computing the ratio. As numbers for assets are usually only available for the ends of reporting periods, the average is an approximation that may not reflect highs or lows between the ends of reporting periods: it implicitly assumes that changes are fairly smooth. The interpretations for ROA and ROE are however the same as ROAA and ROAE respectively. However ROAA is used as the main measure of profitability. From this point onwards, ROA and ROE is used to mean ROAA and ROAE respectively in this study.

Standard Asset Pricing Models imply that arbitrage should ensure that riskier assets are remunerated with higher returns. Banks profitability should therefore reflect bank-specific risk, as well as macroeconomic risks or non-diversifiable (systemic) risk. In the light of this, most studies on determinants of profitability of commercial banks have considered bank-specific factors (internal factors) as well as industry or macroeconomic factors also known as external factors. The external factors can further be divided into macroeconomic factors and financial structure factors.

\subsection{Determinants of Bank Profitability}

This section explores the empirical literature and the various methods used in studying commercial bank's profitability. The available empirical evidence tend to show that studies on banking have extensively been concentrated more on developed and a few developing countries and limitedly on SSA. There is thus insufficient information on the determinants of bank performance in SSA that would require further investigation (Short, 1979; Bourke, 1989; Molyneux and Thornton, 1992; Demerguc-unt and Huizinga, 2001). In theory, bank profitability determinants are categorized into three indicators: bank-specific, industry-specific and macroeconomic. Bank specific indicators include: growth in bank assets, capital adequacy, operational efficiency, and liquidity. The common measure for industry-specific representative used in the various studies is bankconcentration. While on the other hand, the key macroeconomic variables include: growth in GDP, GDP-percapita, inflation expectation, interest rate and its spread. The empirical evidence provides the various methods employed in studying bank profitability using these determinants. Much of the empirical literature agrees that bank level as well and macroeconomic factors largely influence bank profitability. There is however limited evidence that industry-specific factors have any influence on bank profitability. It is against this background that the study utilized only bank level and macroeconomic factors to estimate profitability. Generally profit 
determinant variables are classified in to two broad categories internal and external factors (variables).

\subsubsection{Internal Determinants}

The internal determinants of commercial banks profitability are those factors which are controlled by the management which account for the inter-firm differences in profitability, given the external environment. Anna P. I. Vong and Hoi Si Chan (2008) define internal determinants of bank profitability as factors that are influenced by a bank's management decisions. As stated by Dr. DevinagaRasiah (2010) internal determinants can be broadly classified into two sub-categories namely financial statement variables and non-financial statements variables. The financial statement variables are determining factors which are directly driven from items in a balance sheet and profit \& loss accounts of the bank. On the other hand, the nonfinancial statement variables are those factors which do not directly displayed on the financial statements accounts.

\subsubsection{Financial Statement Variables}

Financial statement variables are those variables which relate to the balance sheet and profit \&loss account. The balance sheet account includes asset, liabilities and equity balances and it indicates the financial position of the firms. Asset management is concerned with the asset portfolio decisions which attempt to maximize returns at an adequate level of liquidity. AGU, CC; (1992), as quoted by DevinagaRasiah (2010), indicated that liability management on the other hand, is concerned with the decisions in relation to deposit mix, borrowings and capital which meet the dual objectives of minimizing funding costs and achieving a desired level of stability in available funds. Hence, asset-liability portfolio decisions would certainly have an impact on commercial bank profitability. Since these decisions are controllable by management, they are thus categorized as internal determinants. The most frequently used bank profitability determinants which are driven from financial statement include;

\section{A. Bank Size}

In most literatures the effect of size on banks profitability are represented by total asset. IndranarainRamlall (2009) indicated that size is used to capture the fact that larger banks are better placed than smaller banks in harnessing economies of scale in transactions and enjoy a higher level of profits. One of the most important questions underlying bank policy is which size optimizes bank profitability. According to Athanasoglouet al., (2005) the effect of a growing size of a bank on profitability has been proved to be positive to a certain extent.

\section{B. Asset Composition}

Asset composition is explained by total loans divided by total asset, provides a measure of the main income source of the bank assets transferred to debtors' (Anna P. I. Vongand Hoi Si Chan, 2008). Traditionally, banks are intermediaries between lenders and borrowers. According to M. Abreu and V. Mendes (2002), other things assumed constant, the more the deposits that are transformed into loans bank performance, the higher the level of profit will be, therefore, it is expected to have a positive relationship with profitability. However, if a bank incurs higher cost on non-performing loans in order to have a higher loan to- asset ratio, then profits may decrease. On the other hand, asset composition is included in the study of profitability as an independent variable to determine the impact of loans on banks' profitability (SairaJavaidet al., 2011). Almost all banking area researchers including M.Abreu and V. Mendes (2002), Dr. Rajesh K. Singh and S. Chaudhary (2009), and DevinagaRasiah (2010) indicate a positive relationship between the amount of loan provided and profitability.

\section{Liquidity Risk}

Liquidity risk is another type of risk for banks; when banks hold a lower amount of liquid assets they are more vulnerable to large deposit withdrawals. In other word liquidity risk, arising from the possible inability of a bank to decreases accommodate liabilities or to fund increases on the assets' side of the balance sheet. Following Saunders and Cornett (2008), liquidity risk refers to the risk that an asset cannot convert into cash or that the conversion is costly. Furthermore, they state that price risk refers to the risk that the sale price will be lower than the purchase price of an asset. It is considered an important determinant of bank profitability Athanasoglou (2006). Therefore, liquidity risk estimated by the ratio of liquid assets to customer deposits and other short term funding. Insufficient liquidity is one of the major reasons of bank failures Ommeren (2011). Liquidity is the quality of an asset that makes it easily convertible into cash with little or no risk of loss. A bank considered liquid when it has sufficient cash and other liquid assets, together with the ability to raise funds quickly from other sources, to enable it to meet its payment obligation and financial commitments in a timely manner.

\subsubsection{Non-Financial Statement Variables}

Non-Financial statement variable comprises variables which have an indirect impact on items in the financial statements while do not directly displayed on the financial statements accounts. Variables reviewed in this category include management quality, efficiency and productivity, age of the bank, and number of branches (Stiroh and Rumble, 2006).

\section{Management Quality}

The management of the banking institution itself is a prerequisite for achieving profitability and stability of a bank. There is evidence that a good management raise profits and market shares (Athanasoglouet al., 2005). On the other hand, where management quality is low and managerial monitoring is imperfect, some lazy workers will not exert full effort on their duties and observing that the remaining good workers may discouraged for work. 
Finally the total sum effect will reduce profitability. In the same vein, according to DevinagaRasiah (2010), where management quality is low and the board of directors does not provide honest and effective leadership, they will often being more concerned with securing credit facilities for themselves, and then prudent lending practices cannot be followed. These have the net effect of increasing the ratio of substandard credits in the bank's credit portfolio and reduce the bank's profitability.

\subsection{Empirical Literature Review}

Profitability of the banking sector is a subject that has received a lot of attention in recent years. There is now a large literature which has examined the role played by management of resources in determining bank profitability.

In addition to the studies discussed, the ensuing discussions highlight some bank profitability studies and empirical results. Samuel Alemu (2015) analyzed determinants of commercial banks profitability: the case of Ethiopian commercial banks. Results suggest Using ROA as a measure of bank profitability; all the bankspecific variables were found to be significant in determining profitability. The results indicate that well capitalized banks are more profitable as capital adequacy had a positive and significant impact on bank profitability. The results also indicate that there is a positive relationship between liquidity and profitability implying that the more liquid a bank is the more profitable it becomes. Concerning asset quality and bank profitability, asset quality measured in terms of the ratio of provision for bad debt to advances has a significant negative impact on bank profitability. This implies as the asset quality deteriorates (credit risk increases) the profitability of the bank also decreases. The study also found a significant negative relationship between operating expense and bank profitability implying that banks are not efficiently translating their expenses into profits. The findings of the study also suggest that large banks tend to enjoy economies of scales as size is positively related to bank profitability.

In contrast to using a single entity, Flaminiet al., (2009) adopted a more comprehensive approach and studied the determinants of commercial banks profitability in the Sub-Saharan African. The analysis is based on a sample of 389 banks, operating in 41 countries from 1998-2006. The results signalled that apart from credit risk, higher returns on assets are associated with larger bank size, activity diversification, and private ownership. Bank returns are affected by macroeconomic variables, suggesting that macroeconomic policies that promote low inflation and stable output growth do boost credit expansion. The results also indicate moderate persistence in profitability. Causation in the Granger sense from returns on assets to capital occurs with a considerable lag, implying that high returns are not immediately retained in the form of equity increases. Thus, the paper gives some support to a policy of imposing higher capital requirements in the region in order to strengthen financial stability.

Li (2000) investigated the impact of bank-specific factors and macroeconomic factors on bank profitability in the UK banking industry over the period 1999-2006. The aim of his study is to demonstrate the strength of risk management in banks. The results showed a negative correlation between loan loss reserves and profitability which was statistically significant. This implied that higher credit risk results in lower profits; a result which is consistent with that Sufian (2009). Capital strength was one of the main determinants of UK banks performance providing support to the argument that well capitalized banks face lower costs of going bankrupt, which reduces their cost of funding (Kosmidou, 2008). Finally, he observed that macroeconomic variables such as inflation, interest rate and GDP growth had insignificant impact on performance.

El Biesi (2010) examined the profitability of foreign banks in nine economies of MENA (Middle East and Northern Africa) economies from 2002 to 2007. Using a panel dataset of 71 foreign banks, the paper investigates the impact of selected macroeconomic, financial market and bank specific determinants on foreign banks profitability. The results show that the most significant factors affecting foreign banks' profitability in MENA are capital, total assets and liquidity ratios at bank level, and stock market capitalization, trade volume, bilateral trade and level of income per capita growth on macro and banking industry level. Furthermore, factors such as concentration ratio, stock market trading volumes and turn over ratios have been investigated but appear to be insignificant factors.

By contrast, fewer studies have looked at bank performance in developing economies. Guru et al. (2002) investigate the determinants of bank profitability in Malaysia. They used a sample of 17 commercial banks during the 1986 to 1995 period. The profitability determinants were divided into two main categories, namely the internal determinants (liquidity, capital adequacy, and expenses management) and the external determinants (ownership, firm size, and economic conditions). The findings revealed that efficient expenses management was one of the most significant in explaining high bank profitability. Among the macro indicators, high interest ratio was associated with low bank profitability and inflation was found to have a positive effect on bank performance. 


\section{Methodology of the Study \\ 3.1 Introduction}

In time series data analysis there are several techniques of parameter estimations including classical regression methods and co integration based techniques. A classical regression method is based on the assumption that all the variables to be included in a regression are stationary. But most macroeconomic variables are non-stationary at level such that estimations based on this technique will be leads to spurious regression. Non-stationary variables may be become stationary through differencing the variables. But such procedure gives only short run dynamics by eliminating long run information. These problems gave birth to a new generation of models based on co-integration and error correction models. There are also several co-integration based methods, but the majority of them suffer from numerous problems when applied to multivariate models. The technique in this category that has emerged as the most powerful and popular is the Johansen technique, which is the technique employed in this study.

\subsection{Nature and Source of Data}

This study used Time Series data from secondary sources mainly from the data center of the Commercial Bank of Ethiopia, MIS department and from annual reports of the Commercial Bank of Ethiopia in annually frequency based over the period 1981 to 2017 . The total annual assets, loans, total annual income, total annual loan provisions, total annual overhead and operational expenses was used to estimate the ratios and coefficients for the internal determinants.

\subsection{Research Design}

The study used quantitative methods of data analysis and the researcher tries to explain the relation between profitability of CBE and its' internal determinants based on the result that found from Co-integration and VAR multivariate regression equations. The data analysis of this research is used Vector Auto Regressive (VAR) model.

\subsection{Functional Relation and Model Specification}

\subsubsection{Functional Relationship}

The functional relation and the expected signs of dependent variable, ROA and its independent variable, i.e. natural logarithm of bank size, operating efficiency, liquidity risk and loan to asset ratio in the following way: ROA $=\mathrm{f}(\mathrm{LN}$ (SIZE), LRR, OER, LAR)

Where:

ROA $=$ Return On Asset

LN (SIZE) $=$ Natural Logarithm of Size of the bank (Asset)

LRR $=$ Liquidity Risk Ratio

$\mathrm{OER}=$ Operating efficiency ratio

$\mathrm{LAR}=$ Loan to Asset ratio

\subsubsection{Model Specification}

\subsubsection{Specification of the Econometric VAR Model}

At the beginning we transformed one variable SIZE under study into natural logarithm LN data to avoid hetroscedasticity and to show elasticity of the variables. Then, the econometric VAR model is specified as the unstructured VAR model.

ROA $=\beta_{0}+\beta_{1}$ LNSIZE $_{t-\mathrm{i}}+\mathrm{B}_{2}$ LRR $_{\mathrm{t}-\mathrm{i}}+\beta_{3}$ OER $_{\mathrm{t}-\mathrm{i}}+\beta_{4} \mathrm{LAR}_{\mathrm{t}-\mathrm{i}}+\varepsilon_{\mathrm{it}} \ldots \ldots \ldots \ldots$. equation $(1)$

Where,

$\beta_{0}$ is constant term

$\beta_{1}, \beta_{2}, \beta_{3}$ and ${ }_{\beta 4}$ are coefficients of $1 \mathrm{x} \mathrm{k}$ matrix to be estimated related with each predictor variables.

$\mathrm{i}=1 \ldots \ldots \ldots \ldots \ldots, \mathrm{k}$ the VAR order

$\varepsilon_{1 t}=$ the error term

$\mathrm{Ln}=$ Natural logarithms of the variables.

The model is linear in the parameters but non-linear in the variables. $\beta_{\mathrm{i}}$ Coefficients are semi-elasticity's and $\varepsilon_{1 \mathrm{t}}$ is stochastic disturbance term with standard properties. The sign of each coefficient is dependent upon the relative contributions of the corresponding explanatory variables which in turn depend on the functioning of the economic system under consideration.

Profitability is the dependent variable of this study. Explanation of dependent and independent variables along with their proxies are specified in Table below. 
Table 1: Explanation of Dependent and Independent Variables Along with their Proxies

\begin{tabular}{|l|l|l|l|}
\hline Variables & Symbol & Explanation & Equations \\
\hline Return on Asset & ROA & Dependent & Net income / Total Asset \\
\hline Liquidity Risk & LRR & Independent & $\begin{array}{l}\text { Cash and Cash equivalent/ total asset } \\
\text { or over withdrawals and other funding }\end{array}$ \\
\hline Bank Size & LNSIZE & Independent & Natural logarithm of Total Assets \\
\hline Operating Efficiency & OER & Independent & Total Expense/ Total Income \\
\hline Asset Composition & LAR & Independent & Total Loan / Total Asset \\
\hline
\end{tabular}

\subsubsection{Specification of Vector Error Correction Model}

In line with equation (1) the error correction model is the change or derivative of equation 1

$\mathrm{D}(\mathrm{ROA})=\Omega *\left(\operatorname{ROA}\left(\mathrm{t}_{\mathrm{i}}\right)+\beta_{1} * \operatorname{LAR}(\mathrm{t}-1)+\beta_{2} * \operatorname{LNSIZE}(\mathrm{t}-\mathrm{i})+\beta_{3} * \operatorname{OER}(\mathrm{t}-\mathrm{i})+\beta_{4} *\left(\operatorname{LRR}\left(\mathrm{t}_{\mathrm{i}-\mathrm{i}}\right)+\pi_{\mathrm{i}} * \mathrm{D}(\mathrm{ROA}(\mathrm{t}-\mathrm{i}))+\right.\right.$ $\mathrm{Y}_{\mathrm{i}} \mathrm{D}(\operatorname{LRR}(\mathrm{t}-\mathrm{i}))+\Phi_{\mathrm{i}} * \mathrm{D}\left(\operatorname{LAR}\left(\mathrm{t}_{\mathrm{t}-\mathrm{i}}\right)\right)+{ }_{\mathrm{TI}} * \mathrm{D}\left(\operatorname{LNSIZE}\left(\mathrm{t}_{\mathrm{i}}\right)\right)+\mu_{\mathrm{i}} * \mathrm{D}(\mathrm{OER}(\mathrm{t}-\mathrm{i}))+\varepsilon_{\mathrm{t}}$

Where: $\Omega$ is the speed of adjustment term or the coefficient of the error term

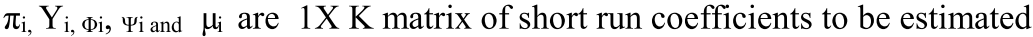

$\mathrm{i}=1,2,3 \ldots$ where $\mathrm{k}$ is lag order

$\varepsilon$ tis vector of exogenous shocks

\subsection{Methods of Data Analysis and Estimation Techniques}

In order to get more precise results the researcher utilized Vector Autoregressive Model (VAR). Because VAR model employee all empirical tools used to estimate the data. Vector autoregressive model (VAR) is one of the most powerful methods of analyzing multivariate data. It is one of the most successful, flexible, and easy to use models for the analysis of multivariate time series. The VAR model has proven to be especially useful for describing the dynamic behavior of economic and financial time series and for forecasting. It often provides superior forecasts to those from uni-variate time series models and elaborate theory-based on simultaneous equations models. Forecasts from VAR models are quite flexible because they can be made conditional on the potential future paths of specified variables in the model.

In addition to data description and forecasting, the VAR model is also used for structural inference and policy analysis. In structural analysis, certain assumptions about the causal structure of the data under investigation are imposed, and the resulting causal impacts of unexpected shocks or innovations to specified variables on the variables in the model are summarized. These causal impacts are usually summarized with impulse response functions and forecast error variance decompositions.

There are some prerequisites dealing with data before realizing VAR models that should be implemented. First, time series included in VAR model have to be stationary. Therefore, unit root test is applied. The test primarily utilizes Augmented Dickey Fuller (ADF). Secondly, the appropriate lag length is determined. And then co integration test, VECM, Granger causality test, Variance Decompositions and finally stability test follows.

The regression analysis known as Co integration and Error Correction model to estimate the relationship between profitability and its determinants was used. This is the distinguishing factor for this study as previous research works on this topic make use of simple OLS Regression technique or Pooled OLS Regressions. To arrive at a result that will not lead to spurious regressions the study tested for stationarityat different levels in the variables making up the model.

Unit Root Tests - Data points are often non stationary or have means, variance and co variance that change over time. Non stationary data as a rule are unpredictable and cannot be modeled or forecasted. Using non stationary time series data in financial models procedure is unreliable and spurious results and leads to poor understanding and forecasting. A non-stationary process with a deterministic trend becomes stationary after removing the trend (Gujarati, 2003).

\section{Dickey-Fuller and the Augmented Dickey-Fuller Tests}

Presence of unit roots of the variables can be examined by Dickey-Fuller (DF) and Augmented Dickey-Fuller (ADF), which is the most frequently, used unit root tests. The DF test estimates the following equation:

$\Delta y_{t}=\delta+\beta_{t}+\alpha y_{t-1}+\varepsilon_{t}$

Where, $y_{t}$ is the relevant time series variable, $\Delta$ is a first difference operator, $t$ is a linear trend and $\varepsilon_{t}$ is the error term. The error term should satisfy the assumptions of normality, constant error variance and independent (uncorrelated) error terms. DF test does not take into account the possible autocorrelation in the error term $\left(\varepsilon_{t}\right)$. The ADF test corrects this shortfall for high-order serial correlation by adding a lagged differenced term on the right-hand side in the DF equation (3.4). ADF employs the following equation:-

$\Delta y_{t}=\delta+\beta_{t}+\alpha y_{t-1}+\sum_{i=2}^{m} \Delta y_{t-i} \varepsilon_{t}$

Both DF and ADF can also be estimated with including a constant and trend term. The null hypothesis is that there exists a unit root in the time series (non-stationary time series), 
Against the alternative hypothesis that the time series is stationary (no unit root) or $I(0)$, In both tests, if the calculated statistic is less (in absolute terms) than the MacKinnon $(1991,1996)$ critical values the null hypothesis is accepted and there is a unit root in the series. In other words, it means the time series is not stationary. The opposite is true when the calculated statistic is greater than the MacKinnon critical value.

Co integration and Vector Error Correction Modeling (VECM) - Most of time series variables are nonstationary individually, but move together over time. In other words the linear combination of non-stationary time series variables may be stationary. In such case, we can say there is co-integration (long run relationship) among variables. Hence testing for co-integration using Engel-Granger two-step procedure (EG) and the Johansen Maximum Likelihood procedure is mandatory.

Analysis of the Dynamic Behavior of the Model

Once the determinants of the ROA are identified in a well-specified model, the interesting issues that remain are how the Profitability reacts to shocks in any of those determinants. The detail discussion of this topic concerns with which shock is relatively the most important and how long, on average, it will take for the ROA to restore its equilibrium following such shock. To show which of the variables in the model have statistically significant influences on the future values of each of the variables in the system, the usual block F-tests and an examination of causality in a VAR can be used. But these tests will not reveal whether changes in a value of a given variable have a negative or positive influence on the other variables in the system or how long it would take for the effect to work through the system (Brooks, 2002). To provide such information impulse response and forecast error variance decomposition analyses for a VAR process with co-integrated variables are used.

\section{Data Analysis and Interpretation}

\subsection{Unit Root Test}

In order to achieve a meaningful regression with time series data it is necessary to test the existence of unit roots in the variables. The variables used in the analysis need to be stationary and/or should be co-integrated in order to infer a meaningful relationship from the regression. The unit root test provides the order of integration at which the variables can be stationary. To detect unit roots both informal and formal tests are employed. The informal test for stationarity is the graphical analysis of time series data. A visual plot of the time series is important in such a way that it gives an idea of the trends and Stationarity of the data set.

From figure 4.1 one can realize that four variables (ROA, LAR, LNSIZE and LRR) seem to be trending upward and the other one variable (OER) trending downward but highly fluctuates over time. They might be stationary or closer to Stationarity boundary as they seem to be hovering around their means.

Figure 4.1 Graphical approaches for unit root test
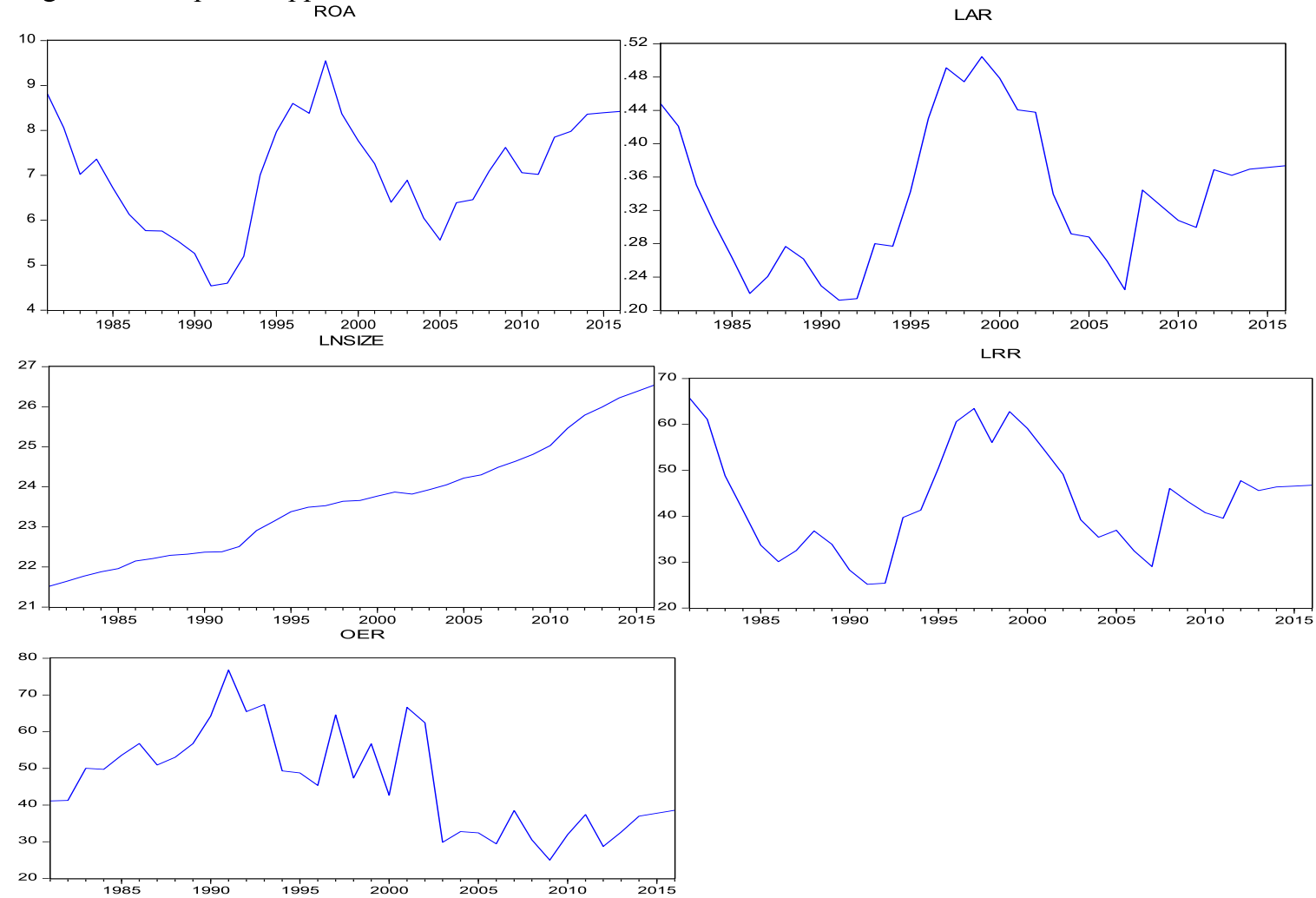

Source: Author's Estimation using EViews 8 
The researcher cannot be deciding whether the variables are stationary or not based on the above graphical analysis alone. To be sure about the Stationarity status of these variables following formal hypotheses testing procedure is necessary. In this study the augmented Dickey-Fuller (ADF) test is used as formal testing technique to detect unit roots and the order of integration of the variables. Concerning deterministic trend assumptions constant is included with no trend. Because according to Brooks (2002), the option with no trend and no intercept produced explosive results, while the option with both a trend and intercept made test statistics less significant. But the alternative with constant and no trend provides us robust results.

Table. 2 Results of unit root tests ADF stationary Test at Levels and at First Difference

\begin{tabular}{|c|c|c|c|c|c|c|c|c|c|c|}
\hline \multicolumn{11}{|l|}{ ADF Test } \\
\hline \multirow{2}{*}{ Variables } & \multicolumn{5}{|l|}{ Intercept } & \multicolumn{5}{|c|}{ Trend and intercept } \\
\hline & At level & P.value & $\begin{array}{l}1^{\text {st }} \\
\text { difference }\end{array}$ & P .value & order[] & At level & P.value & $\begin{array}{l}1^{\text {st }} \\
\text { difference }\end{array}$ & P .value & order[] \\
\hline ROA & -1.790003 & 0.3791 & -4.583227 & 0.0008 & $\begin{array}{l}1] \text { at } \\
1 \%\end{array}$ & -2.287545 & 0.4294 & -4.625097 & 0.0040 & $\begin{array}{l}1] \text { at } \\
1 \%\end{array}$ \\
\hline LRR & -2.364533 & 0.1587 & -5.283103 & 0.0002 & $\begin{array}{l}1] \text { at } \\
1 \%\end{array}$ & -2.406574 & 0.3700 & -5.585820 & 0.0007 & $\begin{array}{l}1] \text { at } \\
1 \%\end{array}$ \\
\hline OER & -2.414737 & 0.1451 & -8.009111 & 0.0000 & $\begin{array}{l}{[1] \text { at }} \\
1 \%\end{array}$ & -3.471828 & 0.0583 & -7.938054 & 0.000 & $\begin{array}{l}{[1] \text { at }} \\
1 \%\end{array}$ \\
\hline LAR & -1.844984 & 0.3534 & -4.399103 & 0.0014 & $\begin{array}{l}1] \text { at } \\
1 \%\end{array}$ & -2.029928 & 0.5652 & -4.395545 & 0.0071 & $\begin{array}{l}1] \text { at } \\
10 \%\end{array}$ \\
\hline LNSIZE & 0.979195 & 0.9954 & -3.234499 & 0.0265 & $\begin{array}{l}{[1] \text { at }} \\
5 \%\end{array}$ & -1.483879 & 0.8155 & -3.511210 & 0.0541 & $\begin{array}{l}{[1] \text { at }} \\
1 \%\end{array}$ \\
\hline \multicolumn{6}{|c|}{$\begin{array}{c}\text { With constant and no trend } \\
\text { Test critical values: } \\
1 \%=-3.639 \\
5 \%=-2.951 \\
10 \%=-2.617\end{array}$} & \multicolumn{5}{|c|}{$\begin{array}{c}\text { With constant and trend } \\
\text { Test critical values: } \\
1 \%=-4.2627 \\
5 \%=-3.5529 \\
10 \%=-3.2096\end{array}$} \\
\hline
\end{tabular}

Source: Author's Estimation using EViews 8

The unit root tests reveal that all variables are non-stationary at levels. When the test is applied to first differences of all variables stationary with constant and with constant and trend, hence the variables are considered as I (1) process. At first difference dependent and all independent variables become stationary with constant and with constant and trend.

The VAR Order (Lag) Selection Analysis

Table 3 VAR Lag Order Selection Criteria

VAR Lag Order Selection Criteria

Endogenous variables: ROA LAR LNSIZE LRR OER

Exogenous variables: $\mathrm{C}$

Date: $03 / 16 / 17$ Time: 17:40

Sample: 19812017

Included observations: 36

\begin{tabular}{lllllll}
\hline \hline Lag & LogL & LR & FPE & AIC & SC & HQ \\
\hline \hline 0 & -231.2427 & NA & 2.863912 & 15.24146 & 15.47275 & 15.31686 \\
1 & -76.11769 & $250.2016^{*}$ & $0.000663^{*}$ & 6.846303 & $8.234032^{*}$ & $7.298668^{*}$ \\
2 & -51.38442 & 31.91390 & 0.000774 & 6.863511 & 9.407682 & 7.692847 \\
3 & -25.89123 & 24.67083 & 0.001104 & $6.831692^{*}$ & 10.53230 & 8.038000 \\
\hline \hline
\end{tabular}

* indicates lag order selected by the criterion

LR: sequential modified LR test statistic (each test at 5\% level)

FPE: Final prediction error

AIC: Akaike information criterion

SC: Schwarz information criterion

HQ: Hannan-Quinn information criterion

Source: Author's Estimation using EViews 8

Here, the appropriate lag length is three. Since, all the information criteria accept AIC (akaike information criterion) supported lag length one, however the most accepted and standardized means of selecting the maximum lag length is the lowest the AIC value. Therefore the lowest the akakie information criteria value is at three. Therefore, we continue to test for co-integration by applying the Johansen (1991) trace and MaximumEigen value co-integration tests. 


\section{Co- integration Test Result}

Once we know VAR lag order, we can apply the Johanson_Juselious maximum likelihood method of co integration to obtain the number of co-integrating vectors.

We have two statistics to test for co-integration, such as trace and max eigen values statistics. Most of the time the trace and maximum eigenvalues statistics might yield conflicting results. To deal with this problem Johansen (1990) recommend basing on one of them to identify the number of co-integration vectors. But Khan (1999), shows that the trace tests are more robust than the maximum eigenvalue statistic in testing for cointegration. Hence to avoid the confusing result of estimation in this paper only the output of trace eigenvalue would present.

\begin{tabular}{|l|l|l|l|l|l|c|}
\hline Null & Alternative & Eigen value & $\begin{array}{c}\text { Trace } \\
\text { statistic }\end{array}$ & $\begin{array}{c}0.05 \\
\text { critical value }\end{array}$ & prob. & $\begin{array}{l}\text { Hypothesized } \\
\text { No. of CE(s) }\end{array}$ \\
\hline $\mathrm{r}=0$ & $\mathrm{r} \geq 0$ & 0.763223 & 95.19257 & 69.81889 & 0.0001 & None * \\
\hline $\mathrm{r} \leq 1$ & $\mathrm{r} \geq 1$ & 0.577045 & 50.53278 & 47.85613 & 0.0274 & At most $1 *$ \\
\hline $\mathrm{r} \leq 2$ & $\mathrm{r} \geq 2$ & 0.318377 & 23.85761 & 29.79707 & 0.2065 & At most 2 \\
\hline $\mathrm{r} \leq 3$ & $\mathrm{r} \geq 3$ & 0.2354457 & 11.97596 & 15.49471 & 0.1581 & At most 3 \\
\hline $\mathrm{r} \leq 4$ & $\mathrm{r} \geq 4$ & 0.111165 & 3.653153 & 3.841466 & 0.0560 & At most 4 \\
\hline
\end{tabular}

Trace test indicates 2 cointegratingeqn(s) at the 0.05 level

* denotes rejection of the hypothesis at the 0.05 level

Source: Author's Estimation using EViews 8

Table 4 Johansen Co-integration Test Result (Trace \& maximum Eigenvalue)

\begin{tabular}{|l|l|l|l|l|l|c|}
\hline Null & Alternative & Eigen value & $\begin{array}{c}\text { Max-Eigen } \\
\text { Statistic }\end{array}$ & $\begin{array}{c}0.05 \\
\text { critical value }\end{array}$ & prob. & $\begin{array}{l}\text { Hypothesized } \\
\text { No. of CE(s) }\end{array}$ \\
\hline $\mathrm{r}=0$ & $\mathrm{r} \geq 0$ & 0.7632233 & 44.65979 & 33.87687 & 0.0018 & None * \\
\hline $\mathrm{r} \leq 1$ & $\mathrm{r} \geq 1$ & 0.577043 & 26.67517 & 27.58434 & 0.0650 & At most 1 \\
\hline $\mathrm{r} \leq 2$ & $\mathrm{r} \geq 2$ & 0.318377 & 11.88165 & 24.13162 & 0.5594 & At most 2 \\
\hline $\mathrm{r} \leq 3$ & $\mathrm{r} \geq 3$ & 0.235457 & 8.322805 & 14.26460 & 0.3468 & At most 3 \\
\hline $\mathrm{r} \leq 4$ & $\mathrm{r} \geq 4$ & 0.111165 & 3.653153 & 3.841466 & 0.0560 & At most 4 \\
\hline
\end{tabular}

Max-eigenvalue test indicates 1 cointegratingeqn(s) at the 0.05 level

* denotes rejection of the hypothesis at the 0.05 level

Source: Author's Estimation using EViews 8

Table 5 Co-integration Rank test - Max eigen value test

The above tables shows that the trace test the null hypothesis of $r=0$ and $r \leq 1$ co-integrating relation is rejected the alternative $r \geq 0$ and $r \geq 1$ co-integrating equations are accepted. This means that there are 2 cointegrating equations because the null hypothesis of $r \leq 2$ could not be rejected in the next step. This is confirmed by comparing the trace statistics ( $\lambda$ trace) with the given critical values. To accept the null hypothesis the critical value at $5 \%$ level significance should be greater than trace statistics.

In the co integration tables, both trace statistics and maximum Eigen value statistic indicated, there is cointegration among the independent (predictable) variables and the dependent variable at $5 \%$ level of significance, suggesting that there is co-integrating or long run relationship among them. The null hypothesis of no co integration equation is rejected by both tests; however the number of co integrating equations at the 0.05 level in both cases is different.

\subsection{Test for Vector Error Correction Model}

A vector error correction model is a restricted VAR model that has co-integration restrictions built in to thespecification. It is designed for use with non-stationary series that are known to be co-integrated. The vector error correction specification restricts the long-run behavior of the endogenous variables to converge to their cointegrating relationships while allowing a wide range of short-run dynamics. The co-integrating term [the error correction term] corrects the deviation from long-run equilibrium gradually through a series of partial short run adjustments.

\subsubsection{The Estimation of Long Run Model}

In determining the variables which are uniquely constitute the co-integrating vectors, the significance of the long-run variables. 
Table 4.7 Co integrating $(\beta)$ Coefficients

\begin{tabular}{llcc}
\hline Variables & Coefficients & Standard error & t-statistics \\
\hline ROA(-1) & 1.0000 & & \\
LRR $(-1)$ & 0.000000 & $(0.92070)$ & {$[-13.7207]$} \\
LAR(-1) & -12.63255 & $(0.08291)$ & {$[5.61818]$} \\
LNSIZE $(-1)$ & 0.465830 & $(0.00717)$ & {$[7.00286]$} \\
OER $(-1)$ & 0.050243 & & \\
& & & \\
\hline C & -16.03994 & & \\
\hline
\end{tabular}

Source: Author's Estimation using EViews 8

Note: The real sign of the coefficients are changed since they are not in the equation form.

Estimation Equation:

$\mathrm{ROA}=\mathrm{C}(1)+\mathrm{C}(2) * \mathrm{LRR}+\mathrm{C}(3) * \mathrm{LAR}+\mathrm{C}(4) * \mathrm{LNSIZE}+\mathrm{C}(5) *(\mathrm{OER})$

Thus, the stable long run relationship is stated in the following way as:

Substituted Coefficients:

ROA $=16.03994+0 *$ LRR + 12.63255*LAR - 0.46583*LNSIZE -0.050243*OER

As indicated above the signs of the coefficients are consistent with theoretical predictions. The t- test statistics indicate that the coefficients of bank size, operating efficiency ratio and loan to asset ratio are significant at 1 percent level. In other words bank size, operating efficiency and asset quality had long run effect on profitability of Commercial Bank of Ethiopia.

\section{Findings and Discussion}

This section of the paper discusses findings and discussions of findings. The objective of the study is identifying and measuring the identified internal factors that determine theprofitability of CBE. Based on the restricted VAR or VECM model analysis the following findings are discussed.

Asset Quality

The coefficient on Loan to asset ratio found for the ROA of CBE is positive and significant at $5 \%$ and $1 \%$ significance level.

There is a positive correlation between loan to asset ratio having low standard errors and a regression coefficient was also statistically significant at $5 \%$ level of significance.

\section{Natural Logarithm of total Asset}

The coefficient on bank size found for the ROA of CBE is negative and significant at $5 \%$ and $1 \%$ significance level.

\section{Operating Efficiency ratio}

The variable operating efficiency ratio (OER) was included in the model to capture the impact of operating efficiency on bank profitability (ROA). As expected, operating expense has a negative and statistically significant relationship with bank profitability according to the regression results.

Liquidity risk

The coefficient on liquidity risk found for the ROA of CBE is zero .The co integration equation (long run relationship of the variables) showed that the liquidity risk of the bank has no long run effect on the profitability of the bank. The co integration result indicates the presence of error correction model.

\section{Conclusions}

The main objective of this study was to examine the internal determinants of financial performance of commercial bank of Ethiopia.

Using ROA as a measure of bank profitability, bank size, asset composition and operating efficiency were found to be significant in determining profitability. The study also found a significant negative relationship between operating expense and bank profitability implying that banks are not efficiently translating their expenses into profits. The effect of the variables on the return on asset has tested as a result the bank size and operating efficiency has negatively affect Return on Asset and statically significant.

The findings of the study also suggest that CBE tend to face diseconomies of scales as size is negatively related to bank profitability. The results also indicate that there is a no long run relationship between liquidity and profitability. Concerning asset quality and bank profitability, asset quality measured in terms of the ratio of loan to asset ratio has a significant positive impact on bank profitability. This implies as the asset quality 
improves the profitability of the bank also increase. Concerning operating efficiency (expense management), the results indicate that expenses management is negative and highly significant determinant of Commercial Bank of Ethiopia (CBE) profitability in terms of returns on asset. Since, expenses management is proxy for management quality, this highly significant and negative coefficient of the cost to income ratio shows the existence of inefficient cost management system (poor quality of management) in CBE. This indicates that, the poor expenses management is one of the main contributors to poor profitability performance of Commercial bank of Ethiopia. The bank is better to adopt new policy on capacity building, continuous training and learning of the management to avoid management inefficiency.

\section{Recommendations}

Based on the findings of the study the following possible recommendations were forwarded:

$>$ Efficient management of bank operations can alleviate the high operational cost that erodes bank profits. Bank occupancy cost and salaries are major components of operational cost. Bank must be encouraged to employ more technologies to automate their service delivery. The use of ATMs and electronic based bank services would reduce the number of branches that would be required. Moreover, these technologies would enable banks to explore new markets without maintaining a physical presence. It would reduce the number of staff costs, occupancy cost, paper cost and queuing times in the banking halls. Bank branches should only be built at strategic locations. Banks must take collaborative and radical steps in building capacity of IT employees to reduce over reliance on foreign consultants who demand outrageous fees for software license and maintenance contracts. Managerial cost and other expenses should be at optimal level and consistent with profit maximization objectives of shareholders.

$>$ According to this study, management efficiency has been the most significant factor in determining the profitability of the Commercial Bank of Ethiopia within the period of 1981-2017.

$>$ The bank should improve managerial efficiency and the bureaucratic bottlenecks system to reduce diseconomy scale of its large size.

$>$ As per the result the LAR has positively and significantly affects profitability of the bank, so in order to boost the level of profitability the bank shall encourage potential Creditors by avoiding various bureaucratic and procedural pre-requests.

$>$ The bank shall encourage the Credit customers by providing various incentive like adopting various loan pricing mechanism based on their level of credit risk,

$>$ Based on the finding of the study, the Commercial bank of Ethiopia is mainly affected by the bank specific factors. Because, most of the bank specific factors had significant impact on bank performance. Since the management of the bank has control over the bank specific factors, it's possible to improve the performance of the bank by giving more attention on the identified bank specific factors such as, bank size, asset quality and operating cost.

\section{References}

Aburime, U. T. (2008) Impact of Political Affiliation on Bank Profitability in Nigeria. African Journal of Accounting, Economics, Finance and Banking Research, Vol.4, No. 4, pp. 61-75.

Adam Mogume (2008), Market Structure and Performance in Uganda Banking Industry.

Athanasoglou, P. P., Sophocles, N. B., \& Delis, M. D. (2008). Bank-specific, industry-specific and macroeconomic determinants of bank profitability. International Financial Markets, Institutions and Money, Vol.18, No.2, 121-136.

Badola, B. and Verma R. (2006). Determinants of profitability of banks in India a multivariate analysis, Delhi Business Review X, Vol. 7, No. 2, pp. $11-19$.

BefekaduDegefe (1995). The development of money, monetary institutions and monetary policy in Ethiopia. An Economic History of Ethiopia: Vol. 1: The Imperial Era 1941-75.

Bikker, J. and Hu, H. (2002). Cyclical patterns in profits, provisioning and lending of banks and pro-cyclicality of the new Basel capital requirements.

BNL Quarterly Review 221, pp.143-175. Bobakova, I.V. (2003). Raising the Profitability of Commercial Banks. Journal of International Finance, Volume XI, and pp. 21-25. Bourke, P. (1989).

Byeongyong, Paul Choi and Mary A. W. (2005). An Empirical Investigation of market structure, efficiency, and performance in property-liability insurance. Journal of Risk and Insurance, Volume 72, pp. 35 - 39.

Clarke, R., Davies, S. and Watterson, M. (1984).The Profitability-Concentration Relation: Market Power or Efficiency. Journal of Industrial Economics, Vol.32, No. 4, pp.435-450.

Commercial Bank Of Ethiopia(CBE) Annual reports 2011/12, 2013/14, 2014/15, and 2016 (Online) from WWW.CBE.Com.et

Cooper, D. C., \& Schindler, P. S. (2009). Business Research Methods. 9th edn.Tata McGraw-Hill. New Delhi.

DeYoung, R. and Hasan, I. 1998. The Performance of Denovo Commercial Banks: A Profit Efficiency Approach. 
Journal of Banking and Finance, Vol.22, pp.567-587.

Flamini, V., McDonald, C. and Schumacher, L. (2009). The Determinants of Commercial Bank profitability in Sub-Saharan Africa. IMF working paper, (09/15).

GedaAlemayehu and Tony A. (2001). Ethiopia's New Financial Sector and Its Regulation, Discussion Paper No.55, pp. $150-211$.

Goldberg, L. G. and Anoop R. (1996). The Structure-performance Relationship for European Banking. Journal of Banking \& Finance, Vol. 20, No. 4, pp. 45-71.

HailegeorgisBelayneh (2011). Determinants of Commercial Banks profitability: an empirical study on Ethiopian commercial banks. Unpublished Master's thesis, Addis Ababa University, School of Business and Public Administration, Addis Ababa.

Haron, S. (2004). Determinants of Islamic Banking profitability. Global Journal of Finance and economics, Vol. 1, No.1, pp. 2 - 22 .

Hellman, Thomas, Murdock, Kevin, Stieglitz, Joseph, E. (2008). Liberalization, moral hazard in banking and prudential regulation: Are capital controls enough? American Economic Review, Vol. 90, No. 1, pp.147165.

Hirtle and Stiroh, 2007) and the banking systems in the western and developed countries (Ho and Tripe, 2002; Williams, 2003

Kosmidou, Tanna and Pasiouras 2006, Determinants of profitability of domestic UK commercial banks: Panel evidence from the period 1995-2002

Kosmidou, K. (2008). The determinants of Bank's profit in Greece during the period of EU Financial Integration. Managerial Finance, Issue, 34, pp. $146-159$.

Kwan, S. and Eisenbeis, R.A. (2005). Bank Risk, Capitalization and Inefficiency. Journal of Multinational Financial Management, Issue, 3, pp. 33 - 48.

Levine, R. (1998). The legal environment, banks, and long run economic growth. Journal of Money, Credit and Banking, Vol. 30, No. 10, 596-613.

Modigliani, F., \& Miller, M. H. (1958). The Cost of Capital, Corporation Finance and the Theory of Investment. The American Review, Vol. 48, No. 3, pp. 261-297.

Molyneux P. and J. Thornton. 1992. "The determinants of European bank profitability", Journal of Banking and Finance, Vol. 16: 1173-1178.

Naceur S. B. 2003, Determinants of the Tunisian Banking Industry Profitability: Panel Evidence. Frontiers in Finance and Economics, 5(1): 106-130

Naceur, S. B., And Goaied, M. (2001).The determinants of commercial bank interest margin and profitability: evidence from Tunisia. Working paper 856365.

National Bank of Ethiopia (2011). Annual report. [Online], available at http://www.nbe.gov.et accessed on December 10, 2011. 